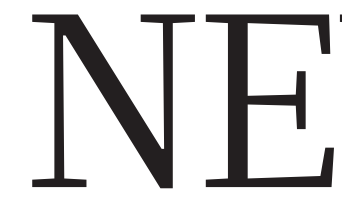

ALTERNATIVE MEDICINE Doubts greet positive outcome of heart therapy $\mathbf{p . 3 1 3}$

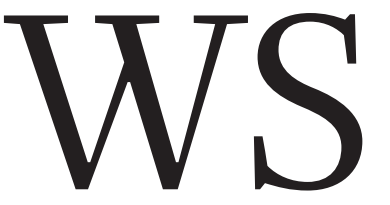

GENOMICS Sow's DNA yields silk purse for researchers p.315
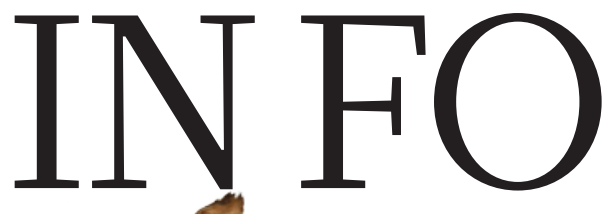

GERMANY Creative funding

for a biomedical powerhouse in Berlin p.317
BIOMEDICINE The man who

challenged fertility

dogma $\mathbf{p . 3 1 8}$

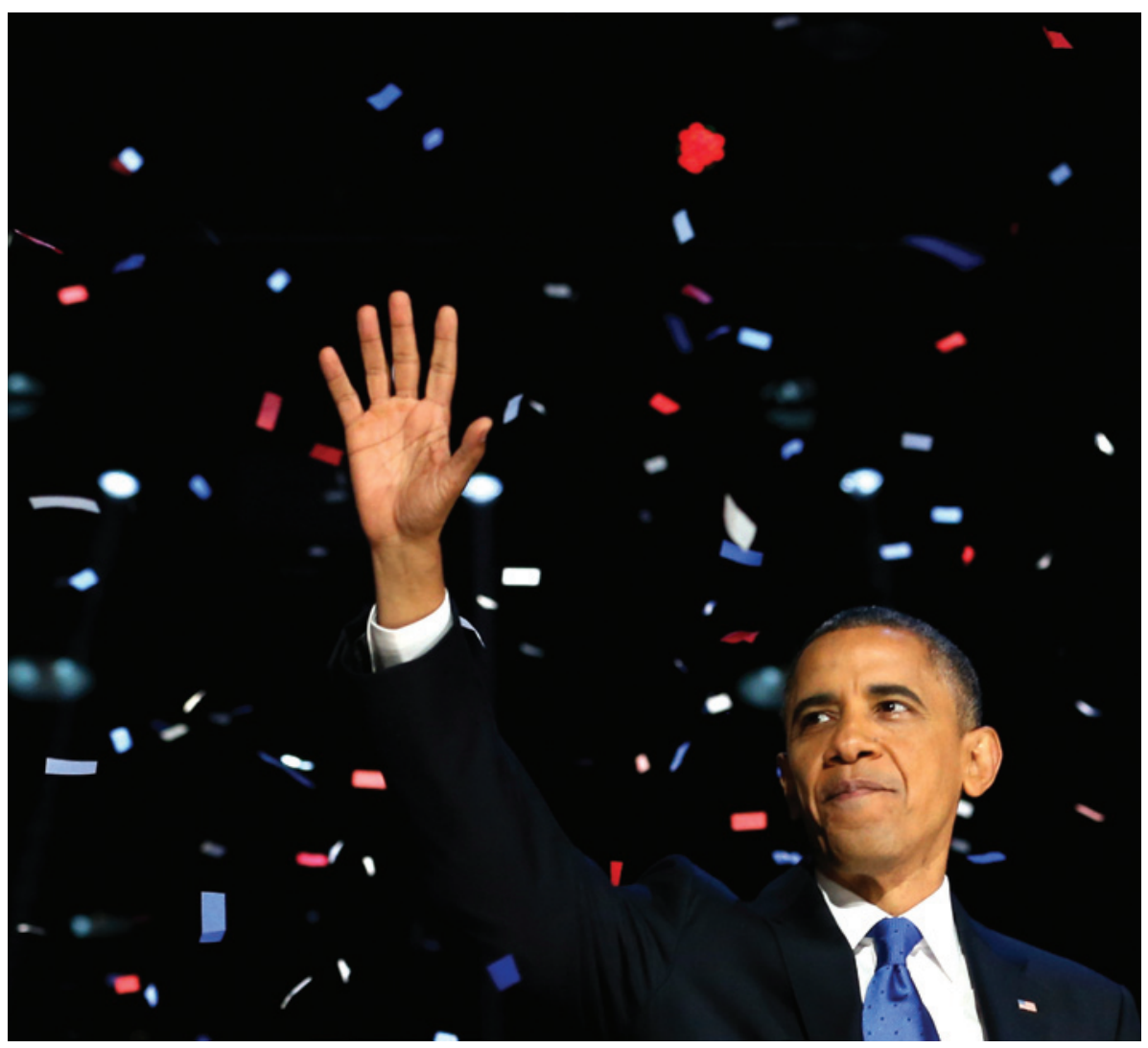

Re-elected US President Barack Obama has won four more years in which to cement his legacy.

POLICY

\title{
Obama reasserts research focus
}

\section{But 'fiscal cliff' threatens science and climate goals.}

\section{BY ERIC HAND, IVAN SEMENIUK, JEFF TOLLEFSON AND MEREDITH WADMAN}

$\mathrm{S}$

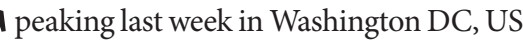
President Barack Obama reminded voters of the plan they had effectively endorsed by re-electing him. One of his key objectives, Obama said, would be to ensure that the United States "is a global leader in research and technology and clean energy, which will attract new companies and high-wage jobs to America”.

A different objective will be in the spotlight this week when Obama visits New York, a city still recovering from the damage caused by Hurricane Sandy on 29 October. Climate change could make storms like Sandy more common in the future. And New York's mayor, Michael Bloomberg, cited climate concerns when he endorsed Obama for re-election (see Nature 491, 167-168; 2012), saying that the president has "taken major steps to reduce our carbon consumption, including setting higher fuel-efficiency standards for cars and trucks". When he accepted that endorsement, Obama acknowledged that "climate change is a threat to our children's future, and we owe it to them os to do something about it".

Yet this new opportunity to confront climate change and invest in science and technology comes with towering obstacles. The election did not end the polarization of Congress - Republicans retained control of the House of Representatives, and the Democrats only slightly strengthened their narrow majority in the Senate. And the 'fiscal cliff' looms large - automatic tax increases and spending cuts, the legacy of earlier budget battles, will hit on 2 January unless the outgoing Congress finds a way to avert them in the session that begins this week (see Nature 487, 414-415; 2012).

The cuts, totalling some US $\$ 136$ billion, would apply to all discretionary spending next year, including defence, and would eat deeply into federal science budgets (see 'At the precipice'). Congressional leaders expect Obama to play an active part in brokering a deal to avoid the fiscal cliff, which economists say could plunge the fragile US economy back into recession. The outcome will foreshadow Obama's prospects for achieving other objectives - including those relevant to science during his second term.

\section{CLIMATE OPPORTUNITY}

Obama may have to develop his climate plans without some high-profile lieutenants. Energy secretary Steven Chu and Environmental Protection Agency (EPA) administrator Lisa Jackson are both rumoured to be stepping down. During Obama's first term, both became lightning rods for Republican attacks — Chu for his role in approving a \$535-million government loan guarantee to Solyndra, a solar-energy company that later went bankrupt, and Jackson for implementing greenhouse-gas regulations. But even without Chu or Jackson, the administration's approach to renewable energy and global warming would change very little, says Michael Gerrard, director of the Center for Climate Change Law at Columbia University in New York. "I suspect we would have continuity in the broad policy approaches."

Obama's election victory, combined with growing alarm in the United States over 


\section{PEOPLE'S CHOICE}

\section{Science at stake in state proposals}

During last week's national election, US voters also weighed in on state ballot measures that affect research.

\section{Hope for higher education}

California voters approved temporary tax increases expected to generate US\$6 billion annually for schools and community colleges through 2017, with smaller revenues through 2019. Passage of the measure also halted imminent state budget cuts that would have cost the University of California (UC) and the California State University system $\$ 250$ million each over one year. UC administrators expressed optimism that the measure heralds a more favourable fiscal and political climate for the institution, which has weathered years of state funding cutbacks.

"Education and research are multi-year endeavours," says Keith Yamamoto, vicechancellor for research at UC San Francisco. "The impact of a lack of stable funding is substantial."

Steve Montiel, a UC spokesman, called the measure "a significant step towards the prospect of financial stability".

\section{Experimentation with marijuana}

Colorado and Washington became the first states to legalize marijuana for non-medical purposes, permitting purchase and use of the drug by adults aged 21 and older. Residents of Colorado can also possess up to six marijuana plants.

The new measures set the stage for a legal battle: federal law prohibits the substance, and the US Drug Enforcement Administration says that its policy "remains unchanged". Opponents fear that looser marijuana laws could lead to more drug abuse in the United States. In studies of drug use in the Netherlands since the country's de facto legalization of marijuana in 1976, Robert MacCoun, a drug-policy expert at the University of California, Berkeley, has found only modest increases in marijuana use and no significant escalation to harder drugs (R. MacCoun and P. Reuter, Science 278, 47-52; 1997).

"Of course, the Netherlands is a different country", but it provides some of the only available data worldwide, MacCoun says. The Washington measure would direct some marijuana tax revenue towards drugabuse research.

\section{No labelling for genetically modified food}

California voters rejected a measure that would have made theirs the first state to require labelling of foods containing genetically modified organisms (GMOs).

Bob Goldberg, a plant geneticist at UC Los Angeles, who co-authored an argument against the proposal in the state's voting guide, calls the measure "ideological and not evidence-based".

Marion Nestle, a food-politics expert at New York University, argues that labelling might have promoted greater consumer trust in GMOs. "Not having a choice induces paranoia in people," she says.

A poll conducted by the California Business Roundtable, a business-advocacy group based in Sacramento, and the School of Public Policy at Pepperdine University in Malibu, California, found that public support for labelling was at around $65 \%$ in August, then plummeted in the month before the election. The opposing campaign - backed heavily by Monsanto, a producer of genetically modified seeds based in St Louis, Missouri - escalated its television advertising in the final weeks. Helen Shen
- severe weather events, such as Hurricane Sandy and the severe drought in the Midwest this summer, could bolster efforts to curb carbon emissions. Jackson laid the foundation for such reductions after the US Supreme Court ruled in 2007 that carbon dioxide is a pollutant, which allowed the EPA to regulate the gas under the Clean Air Act. Jackson went on to craft the first US greenhouse-gas regulations for vehicles, and in March proposed a rule that would effectively ban the construction of new coal-fired power plants unless they are equipped to capture and sequester roughly $50 \%$ of the carbon dioxide they emit. The agency next plans to propose rules for existing power plants, then oil refineries. The details of those rules are unclear. The EPA could, for example, set energy-efficiency standards for different types of power plant or take a more flexible approach that would let states - which normally implement air-quality rules - decide how to proceed.

There is also an outside possibility that Congress's struggle to avoid the fiscal cliff could bring another approach to the fore: a carbon tax. To avoid the automatic spending cuts and tax rises, lawmakers must find new ways to raise revenue. So far, the House has focused on closing tax loopholes, but those efforts are expected to come up short. As an alternative, a carbon tax has been quietly gaining traction in policy meetings, even among some conservatives.

"A carbon tax is certainly not likely as a starting point, but we think it could become extremely attractive if the lawmakers begin to run out of options for generating revenue," says Mark Muro, a senior fellow at the Brookings Institution, a non-partisan think tank in Washington DC.

Although the idea of any tax - let alone one on carbon - is anathema to most conservatives on Capitol Hill, the idea offers something for everybody in the current budget crunch. A tax would reduce emissions and raise revenue for energy research and development - outcomes that environmentalists would welcome - and it would generate extra revenue that conservative lawmakers could use to offset lower tax rates on individuals and businesses.

In August, economists at the Massachusetts Institute of Technology (MIT) in Cambridge reported that the United States could raise \$1.5 trillion over ten years and reduce emissions to $14 \%$ below 2006 levels by 2020 by instituting a tax of \$20 per tonne of carbon in 2013 and increasing it by $4 \%$ a year. Less than $20 \%$ of that revenue would be enough to fund a massive boost in federal investments in clean-energy research and development - from $\$ 3.8$ billion in 2012 to $\$ 30$ billion annually, Muro says. The administration has yet to weigh in on the idea, and some on Capitol Hill think that is just as well. If pushed prematurely, the idea could wither in the political spotlight before lawmakers have a chance to fully consider its merits. "We're trying to generate interest," a senior House aide told Nature. "The more discussion there is, the better."

\section{FUNDING FEARS}

Basic research has historically fared well under Democratic and Republican administrations, but many university administrators were nonetheless relieved by the election's outcome. They wondered whether Republican candidate Mitt Romney would side with other Republicans - including Paul Ryan, his running mate and chairman of the House budget committee - who advocate severe spending cuts to government programmes as a way of reducing the deficit. "Thank God we don't have to find out," says Stewart Smith, dean for research at Princeton University in New Jersey.

Universities that receive grant money from federal science agencies are nonetheless bracing themselves for the fiscal cliff that awaits if Congress cannot reach a budget deal or find a way to extend the bargaining window

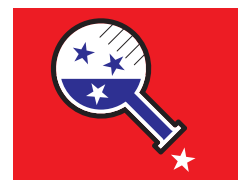

$\rightarrow$ NATURE.COM Visit Nature's election special: www.nature.com/ election2012 before 2 January. The administration's Office of Management and Budget estimates that most funding agencies would have their budgets slashed by $8.2 \%$ in the absence of an agreement. Claude Canizares, vicepresident for research at MIT, says that the result 

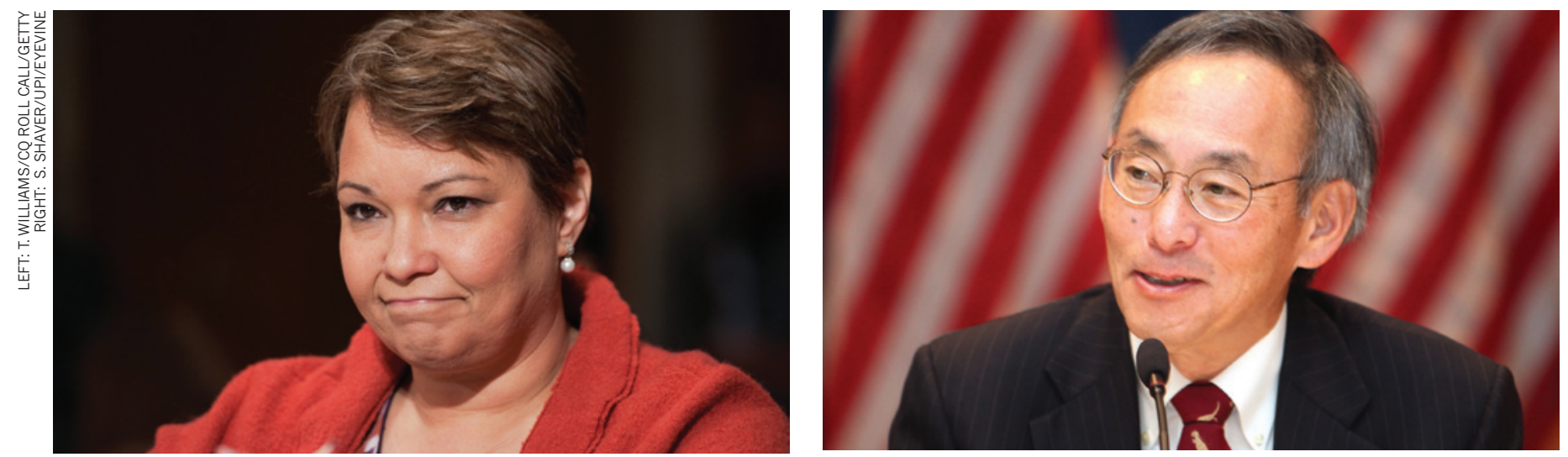

US Environmental Protection Agency administrator Lisa Jackson (left) and energy secretary Steven Chu (right) drew much Republican ire in 2008-12.

would be a loss of $\$ 40$ million in research revenue at the university, which drew $\$ 619$ million in research support in 2011. An $8 \%$ cut in funding to the US Department of Energy (DOE) would mean an $8 \%$ loss in staff at the DOE Princeton Plasma Physics Laboratory, of which Smith will become vice-president in January.

Advocates for biomedical research are equally concerned about the prospect of the cuts. "I don't know how you spare anyone or anything" at the US National Institutes of Health (NIH), says Jennifer Zeitzer, director of legislative affairs at the Federation of American Societies for Experimental Biology in Bethesda, Maryland. The automatic cuts would slash the agency's $\$ 30.7$-billion budget by $\$ 2.5$ billion, a portion of which would be exacted from every NIH institute and centre.

That prospect, in combination with other pressures on medical research budgets, is "chilling", says Ann Bonham, chief scientific officer at the Association of American Medical Colleges in Washington DC. She notes that the Patient Protection and Affordable Care Act, the health-care-reform law that is the signature policy achievement of Obama's first term and will ultimately extend health insurance to more than 30 million now-uninsured US citizens, also mandates a \$155-billion cut in government payments to hospitals. That could hurt the large teaching hospitals that support much US medical research (see Nature 487, 13-14; 2012). Bonham worries that the confluence of stresses will consign the biomedical research enterprise to "death by 1,000 cuts".

Supporters of Obama's health-care reform argue that it will eventually curb soaring US government outlays for health care, thereby shrinking the deficit and producing more revenue for agencies, including the NIH. If the plan works, the reform is "likely to be a longterm gain for research", says Ezekiel Emanuel, a medical ethicist and health-policy expert at the University of Pennsylvania in Philadelphia, who was the senior health-policy adviser to the White House budget office from 2009-11.

\section{AT THE PRECIPICE}

Annual US funding for non-military research and development will drop sharply if government-wide budget cuts take effect (red). If defence spending is spared, even deeper cuts will apply (blue).

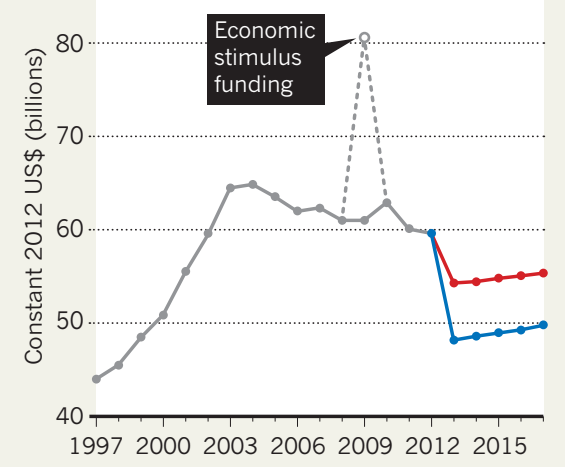

Science could also benefit from another Obama goal: immigration reform. One result of such reform could be more ' $\mathrm{H}-1 \mathrm{~B}$ ' visas for foreign scientists and engineers, a need that both candidates emphasized during the campaign.

In the meantime, Obama's science agenda will depend on cooperation with a Congress that includes some new faces. Last week's general election not only returned him to office and decided state ballot measures (see 'People's choice'); it also marked the end of some key lawmakers' terms. The chairmanship of the Senate energy and water committee is being vacated by the retiring Jeff Bingaman, a Democrat from New Mexico. Some observers expect Ron Wyden, a Democrat from environmentally friendly Oregon, to fill the spot. Although generally liberal, Wyden is known for crossing the aisle to work with Republicans. "Wyden is a very thoughtful guy; he likes to think outside the box," says Michael Lubell, director of public affairs for the American Physical Society in Washington DC.

In the House, it's unclear who will chair the spending subcommittee that funds the NIH. The current chairman, Denny Rehberg of Montana, relinquished his House seat in a failed bid for the Senate. The science, space and technology committee is losing its chairman, Ralph Hall of Texas, who is stepping down in accordance with Republican term limits. Jim Sensenbrenner of Wisconsin, Dana Rohrabacher of California and Lamar Smith of Texas all want the job. Lubell says that his money is on Smith, a co-sponsor of patentreform legislation who has also tried to make it easier for foreign graduates with science degrees to remain in the United States.

For now, Obama's victory has created an opening for compromise after two years of Congressional gridlock. With the fiscal clock ticking, the coming weeks may well set the tone for the next four years. a SEE EDITORIAL P. 30I

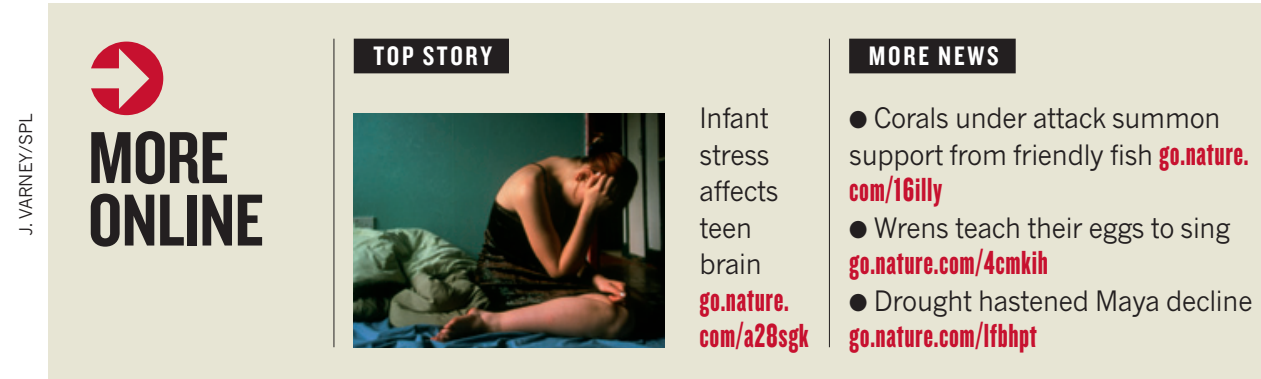

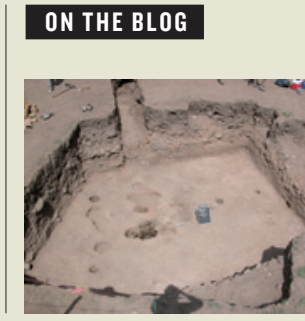

Pre-

Columbian fossil collectors unearthed go.nature.com/ fujihy 